\title{
Nationalism in Badr Shaker Al-Sayyab's Revolutionary Poetry and its Influence on Arabic Poetry
}

\author{
Shaimaa Hassanin, PhD \\ Horus University, Egypt
}

Doi:10.19044/esj.2020.v16n14p53～URL:http://dx.doi.org/10.19044/esj.2020.v16n14p53

\begin{abstract}
This paper contends that Badr Shaker Al-Sayyab's use of mythical and symbolic figures shows the impact of foreign and Arabic poetry on the history of humanity. It Appears that Al-Sayyab restored the ancient mythologies of his nation and exchanged this them with Anglo-American culture to handle the praxis of life and reflect the verifiable circumstances of the Middle East, particularly that of his nation, Iraq. This paper reevaluates Al-Sayyab's poetry from a different perspective which reflects the socio-political unsetting within the Middle East. Al-Sayyab does not essentially duplicate Eliot's methods, symbolism and themes. Rather, he mixes them with his legendary vision to form a wealthy and widespread national poetry without neglecting or sacrificing the national orientations of his poems. The relationship between Al-Sayyab and other poets is one of subversion and alterations; not essentially one of a simple ongoing impact. Al-Sayyab progressed the myths utilized by Eliot and other poets and changed them to modernize his poetry. Critically, he utilizes myth in an organized and systematic way to compare the current subjects of his lyrics against inaccessible and legendary ones.
\end{abstract}

Keywords: Myth, Eliot, Al-Sayyab, Modernism, Comparative Literature

\section{Introduction}

Bader Shaker Al-Sayyab (1926-1964) is an Arab productive poet who introduces the movement of modernism to Arabic poetry. Modernism is an intellectual and creative movement that holds purposeful publicity and geological boundaries. It is formulated as an inner modification within the human soul with regard to the world by the help of the poets. It becomes a demanding need to revolutionize the themes of poetry in a setting that suits the social, economic and political unsettling in the Middle East, especially after WWII. Al-Sayyab was one of the poets who recognized that there is a must to innovate the topics of Arabic poetry to cope up with the challenges of 
the movement of modernism. Al-Sayyab is "a creator of the revolution in modern Arabic poetry." (Haidar, 1986, p.7).

In the middle of the Twentieth century, poetic devices around the world were available to poets of the Middle East to utilize and associate with new patterns and movements. Specifically, poets used different imagery and surrealism; more importantly, the events of the Palestinian calamity in 1948 encouraged many poets to use new themes and techniques. One group of artists turns to common poetry since their need for potential poetic techniques becomes necessary. Another group, to which Al-Sayyab belongs, is pulled into modernism and is committed to its standards by utilizing typical images with mythical figures and themes. The new Arabic poetry, Haidar declares, "is characterized by the use of abstract symbols and imaginative images rather than direct expression." (Haidar, 1986, p.7) This modern poetry should be suggestive and illusionistic by the help of Arab pioneer poets.

\section{Importance of the Study}

This paper tries to prove that Al-Sayyab was much influenced by the English romantic poets, like Wordsworth, Shelley and Keats. He devoted some of his poems to romanticism and romantics, and he indeed deciphered few of their works and incorporated them in his poems. Likely, modernists as Eliot impacted him more, especially in his organized evolvement of the poem. His internalization of innovated subjects and techniques does not shock us since modernism was a universal development in range. As the foremost particular voice of Middle East modernism, Al-Sayyab developed "hybridized poetics tending to the new substances developing within the Middle East region "in the post-WWII period." (Gohar, 2008, pp.42- 47) He implanted the roots of modernism in Arabic poetry through his persuasive use of verbalized phrasing and Eliot's techniques of modern poetry.

\section{Aims of the study}

This paper is mainly concerned with highlighting the noteworthy position of Arabic poetry among world literary works, and its relationship with English and American poetry. Moreover, it explores the different degrees of hybridity and acculturation between the Middle East and the West. It endeavors to follow the sources of Arabic poetry's innovation to assert the social identity of the Middle East. The poetry of Badr Shaker Al-Sayyab is the core of this study to show the mutual influences of other English and American writers. Also, his use of myths and symbolism is going to be explored to show the influence of poetry on different cultures and civilizations. 


\section{Theory and Method}

The contextual approach will be used through this paper; it seeks the literal meanings of the text and its formal properties. Also, it emphasizes the unity of construction, the main symbols and figures of speech. The contextual approach is a branch of literary criticism that is concerned with deciding the precision of literary works by examining the accuracy of the text. It is concentrates on the procedure of reestablishing writings to be conceivable to their original forms. It is an investigation of a content that makes a difference in evaluating the content through its historical and social settings. Moreover, the textual analysis combines the features of formal analysis with the features of cultural archeology and the systematic study of social, historical, political, economic conditions that have been taken place when the text was written. Whereas this may sound complicated, the textual analysis implies situating the content inside the milieu of its time and evaluating the literary text of the writer.

\section{Discussion}

The effect of Eliot and his poem, The Waste Land, on modern Arabic poetry is like that of Al-Sayyab, Al-Bayati and Al-Mala'ikah; a poetry that breaks with the convention of classical lyrics, receives free shapes of verse and employs allegorical expressions utilizing symbolism and imagery. This gigantic move from the ordinary lyric of Al-Qaida to Al-shi'r Al-hurr, free verse, plays a critical role in influencing the prospering results of the Middle East artists; especially Al-Sayyab who exchanges his deference of Eliot's strategies and typical fashion to go "past the general impediment of the sentimental encounter." (Badawi, 1975, p.251), which is clearly portrayed in his romantic collection "The Rain Song" "Unshudat Al-Matar". This collection is not significantly lauded and recognized for using free poetry, but also for the use of symbolism and its mythical and typical designs, which AlSayyab derived from Eliot.

Emran affirms the mutual relations between Al-Sayyab and other poets, and she contends that Al-Sayyab was "exceedingly person and independent" as he "turns to the wealthy bequest of his process country to resuscitate recollections of the splendor of old Mesopotamia." (Emran, 2000, p.V). In such a case, Al-Sayyab displays the Eliotic issues and utilizes similar symbols, procedures and images. He uses the myths of Tammuz and Ishtar to add a diverse profundity to his work established in the cultural legacy of his nation. By doing so, he came to be known as the Tammuzi artist.

Like other writers and scholars of his era, Al-Sayyab respected Communism and became a member of the Iraqi Communist party. The Iraqi patriot parties and the Communist party were in a strife due to the communist party's demeanor towards the Palestinian issue. Al-Sayyab was more a writer 
than a lawmaker; hence, he is more immersed into the Western verse of Edith Sitwell and T.S. Eliot to highlight disdain towards strife and the Western powers and the struggle between Communism and Colonialism. He criticized the hopeless of the socio-political circumstances in Iraq and the Middle East through his poetry. In fact, Al- Sayyab's poetry uncovers how he was reflective and subjective in various situations.

As Al-Sayyab lived in a period of turmoil and patriot developments, he freed Arabic poetry from mono rhyme and the monometer that were presented in traditional Arabic poetry. Such an infringement of the Arabic poetic rules (metric rules and rhyme) is considered as a critical development within the history of Arabic poetry. Eventually, Al-Sayyab's Rain Song is regarded as one of the foremost noteworthy lyrics in Arabic innovative verse composed in free verse, employing a new diction with solid and explanatory words which gave validity to the development of Arabic free poetry. AlSayyab utilized different new techniques, such as myths, monolog, discourse, incongruity, offbeat allegory and symbolism. Moreover, he dealt with modern themes in poetry like town, nationalism, death and alienation. In fact, AlSayyab is the pioneer who established, through a fine idyllic commitment unrivaled within the fifties, few of the essential tenets of Arabic scholarly innovation.

In Jaikur, a small town in Basra south Iraq, Badr Shaker Al-Sayyab was born and brought up to end up as one of the innovative pioneers of Arabic free poetry. Despite passing away at the age of thirty-eight, his poetry holds a prominent place in Arabic culture. His hometown, Jaikur, was figured essentially in his scholarly career. Subsequently, it is not a surprise that his lyrics immortalize Jaikur. His journey of enduring distress began when his mother died while he was only six. Al-Sayyab started his education in Bab Suliman town till the fourth grade, and afterwards he moved to Abu AlKhasib. When he completed his elementary education, he moved to Al-Basra city for secondary school. After his graduation in 1942, he moved to Baghdad and joined the Higher Teacher Training College in 1943. There, he joined the office of Arabic writing for two long stages, when he was ceased from college in 1946 for seven months in charge of being a supporter of the communist party. Afterwards, he was captured for taking part in a conspiracy against the British mandate in Palestine. After being discharged, Al-Sayyab returned to his college, but he changed his course from Arabic writing to English one.

In 1948, Al-Sayyab graduated from college and worked as an English dialect instructor in Al-Ramadi Tall school. At this school, Al-Sayyab got an opportunity to restart his political activities. In other words, he engendered in a classless society. Afterwards, he went through three months of education and training, but due to his communist background he was fired. After being jailed for three months, he was discharged. Consequently, he disappointingly went 
back to his hometown as an unemployed person. Later on, Al-Sayyab got a job at an oil company in Al-Basra city and worked there for a year and after that he moved to Baghdad. Al-Sayyab realized that Baghdad was the right place for him to continue his education and to get a job. In Baghdad, AlSayyab was immersed in political activities again. In 1952, Al-Sayyab was denounced of prompting viciousness and clutter in Baghdad by activating the burning of a police station; a behavior that helped in eluding numerous individuals. Thus, police started to track those who rampaged the city of Baghdad by vandalizing, assaulting, killing and pulverizing them. These smoking-out operations constrained him, so he had to mask himself as a Bedouin to elude to Iran and then to Kuwait, where he remained for six months. In Kuwait he met other members of the Iraqi communist party who had fled from Iraq.

In this sense, Al-Sayyab internalized a "historical background" that permitted him to see his poetic potential as a part of the poetry of forerunners, but without relinquishing his possess. Receiving free verse permitted AlSayyab to discover a medium that encourages the smoth transition between poetry and verse, by utilizing emotional components and other principal gadgets borrowed from Eliot's verse, such as enclosures for comparing two situations with an important one or utilizing brackets to clarify the relationship between past and present. By doing so, the association between thoughts and emotions would be clarified. Afterwards, Al-Sayyab outlined through his collection "Unshudat al-Matar" what Eliot alludes to in his paper on Hamlet, "The Objective Correlative". Through this paper, Eliot clarifies that "inventiveness of expression must depend on a relationship between external facts and emotions." (Eliot, 2019, p.2) So, poets dodge communicating feelings straightforwardly. As a result, Al-Sayyab utilized idyllic images and put some of his symbols as legendary status without depleting his treatment of themes.

Al-Sayyab, as an artist had an abhorrence to tolerate forced limitations and dazzle accommodation to the arrangement of the communist party. The debate between Al-Sayyab and the communist party members started since Al-Sayyab's inclination of studying Eliot and Shakespeare over the Russian communist scholars. In fact, Shakespeare and T.S. Eliot are reactionary poets, whereas the communist writers are magnanimous, dynamic and radical. In this manner, Al-Sayyab was upbraided and was denounced of traitorousness to the communist party. When he was in Kuwait, he wrote magnificent lyrics, such as Arms and Children, The Daze Prostitute, A Stranger on the Inlet and the Rain Song, which was afterwards published in his collection Unshudat AlMatar (The Rain Song). This period of his life influenced him greatly and helped shape his thoughts and character as a revolutionary poet and a political activist. 
In fact, Al-Sayyab was born amid the British mandate in Iraq and had witnessed the WWII, the establishment of Israel and numerous other turbulent occasions that occurred in the forties, fifties and sixties of the twentieth century. Al-Sayyab lived a hopeless life amid political changes, like Iraqi oligarchic government with its restrictions. As a result, after the transformation of 1958, Al-Sayyab was detained and got fired from his work. In 1961, he traveled to Rome to participate in a conference, as he was received as a speaker of advanced Arabic writings. When he returned to Baghdad, AlSayyab started his journey of anguish by regretting his destiny:

Like that, do the years go by?

Like that, does the life dry out?

I feel I am wasting away

Getting fatigued

Dying like trees. (Al-Sayyab, 2000, p.20)

Al-Sayyab's health remarkbly started to decline, and later he joined a healing center in Beirut. In such a stage of his life, his poetry witnessed a twist of thoughts. He wrote a poem where he asked his wife, Iqbal, to forgive him and asked her to be caring, kind-hearted and thoughtful to their children:

Oh, Iqbal, my beloved wife

Chide me not; never is death in my hand

And I am not, if saved, immortal

Be for Ghailan solicitousness and kindliness

Be for him a father and a mother

And have mercy on his wailing. (Al-Sayyab, 2000, p.21)

Al-Sayyab fed his talent by perusing almost of Arabic poetry legacy, Iraqi mythologies, and books of scriptures. Besides, he examined his ancestors like Al-Mutanabi, Abu Tammam and Al-Buhturi along with modern Arabic writings particularly the Mahjar verse (verse of Middle Eastern artists who were displaced from their countries) Al-Sayyab is inquisitive about romantic poetry, and he was profoundly affected by the Lebanese romantic poet, Ilyas Abu Shabakah. When he was studying English literature, Al-Sayyab considered Shakespeare, Shelly and Milton to be his idols. In addition, he profoundly appreciated the English innovative writers like T.S. Eliot and Edith Sitwell. Al-Sayyab studied translated French poetry, especially the poems of Charles Baudelaire. Also, he studied Arabic, Russian and English literary works. He set up his reputation as a talented poet among his colleaguesin the Arab world:

Oh, what I gained from time, but melancholy and emaciation.

Or I observe the long night dissolves into the long morning And I attend to the swaying beam of the sun to its final dissipation 
And I escort the monotonous (full) moon, vanishes in the palm trees.

Neither much hope nor little plea do I have

And I count my days to hand them over to the heavy grief. (Abbas, 1966, p.

55)

Al-Sayyab's second collection Assateer (Myths) published in 1950, was written within the penultimate year of his study. This collection uncovers the duality of the poet's nature, where he compared different images of cherishing and dying, light and dull. In this collection, the poets' double identity is displayed sometimes as a struggler, striver and in other times as retrogressive and thoughtful. Al-Sayyab enjoyed a positive attitude towards women and usually uncovers his suffering after the early loss of his mother. Because of his longing for protection and affection, he went through his life looking for a replacement to compensate him.

Al-Sayyab's collection Unshudat Al-Matar (The Rain Song) clarifies the present stage of Arabic poetry with its modern topics, particularly the use of images and myths. This collection contains thirty-two poems including his popular poem, Unshudat Al-Matar (The Rain Song). Numerous sonnets in this collection were translated into English. This collection (The Rain Song) was composed in 1953 when he was in Kuwait as an oust. This celebrated sonnet was translated into English fourteen times; indeed, its title has been rendered into English in different ways like Hymn of Rain, Rain Song, The Rain Tune and The Rain Song. When (The Rain Song) was published in Al-Adab (Literature) Magazine in 1954 for the first time, it set up the popularity of A1Sayyab's poetry among his counterparts since its innovative topic and solid phrasing. The poem played a key role in fortifying Arabic poetry as an unprecedented form in Arabic poetry. Critics and journalists have analyzed Al-Sayyab's The Rain Song more than his other lyrics for its modern and unique images. Al-Sayyab's lyrics, The Rain Song, is much more than a tune or a Psalm which celebrates precipitation or disclosure of the poet's sentiments of joy when he observes the drops of rain. In fact, the lyrics incorporate a diverse measurement. Here, rain does not allude to a resurrection of nature or life among fruitless and barren lands, but it incorporates political issues and measurements. On one hand, it expresses the writer's resistance to the administration of Nuri Al-Said. On the other hand, the poem uncovers the poet's profound anguish, instead of happiness and pleasure. Therefore, the drops of rain are allegorically related to the drops of tears. The extremity between the picture of rain within the title of the sonnet, and what it really communicates within the substances emphasizes the conflicting life of Middles easterners who enormously endure from hopelessness and financial discouragement in showing disdain toward the colossal and insignificant assets within the Middle easterner world. The word rain depicts life, ripeness 
and restoration; the word song or hymn indicates bliss and felicity. Anyway, Al-Sayyab's lexical choice of the word rain is noteworthy, as it emphasizes tears, deploring, passing, starvation, destitution, migration and the hopelessness of the Iraqi citizens. The Rain Cry would have been a suitable interpretation of the conditions of his people. Al-Sayyab unexpectedly called it The Rain Song, whereas Iraqi citizens endure wretchedness life despite the colossal common assets and the richeness of the nation:

I cry to the Gulf, - $\mathrm{O}$ Gulf,

$\mathrm{O}$ giver of pearls, shells and death.

The echo comes back

Like sobs,

-O Gulf,

$\mathrm{O}$ giver of shells and death

I can almost hear Iraq gathering thunder

And storing up lightning in mountains and plains

And there is hunger in Iraq!

The harvest season scatters the crops in it

So that ravens and locusts have their full

While a millstone in the fields surrounded by human beings

Grinds the granaries and the stones. (Al-Sayyab, 2000, pp. 47-52)

In fact, Al-Sayyab's artistic life has gone through three stages: the emotional stage (1934-1948), the Authenticity stage (1949-1955) and the Tammuzian stage (1961-1964). He composed national poems that express and illustrate his solidarity to the Arab world issues such as; Jamila Bouhreed and Risalah min Maqbarah (A Message from the grave). Moreover, he wrote political lyrics such as Min Ru'ya Fukai [From Fukai's Vision], Al-Mabgha Al-Awdah li Jaikur [Return to Jaikur]. Another critical angle of his scholarly career is that he studied Fraser's The Brilliant Bough and composed numerous poems that discuss mythology such as: $A l$ Masih Terrible al-Salb (Christ after Crussification). In addition, Al-Sayyab's verse turned to be exceptionally individual and enthusiastic due to his profound anguish to the unequivocal, inescapable and sorrowful farewell to his wife and children. From his childhood untill his passing, Al-Sayyab's life was an agonizing traveler. He was stranded in his childhood, abused in his youth, and he inevitably was struck by deadly ailment.

On the other hand, Eliot theorized the poet's relationship with the past in his article - Tradition and Individual Talent. He declared that the authentic sense of the social legacy is fundamental to the artist. In his poem, The Waste Land, Eliot joins his hypothesis with his hone by insinuating to old scholarly 
works and mythologies. Al-Sayyab and Eliot associated the past and displayed it by utilizing ancient myths and implications to the antiquated scholarly writings. For example, in his lyrics: Shanasheel Ibnat Al-Jalabi [The Balcony of the Nobleman's Daughter], -Unshudat Al-Matar (The Rain Song), AlSayyab alluded to some historical stories mentioned in the Holy Quran such as the story of Qabil, Thamud, Yajuj and Majuj, Abraha, Kaba, Hira, Mohammed, and Maryam [Mary]. Al-Sayyab also alluded to the historical Arab figures such as Al-Basus, Al-Shimr in his poem, Marthiyat Jaikur [Elegy on Jaikur]. Moreover, in his poems: Al-Sha'ir al-Rajeem [The Evil Poet], -Unshudat Al-Matar [The Rain Song], Al-Sayyab implied to numerous old myths such as Tammuz, Persephone, Zeus, Apollo, Tantalus, Midas, Cerberus, Ganymede, Attis, Ishtar, and Narcissus. Essentially, Eliot cited from the ancient scholarly works of Homer, Virgil, Dante, Chaucer, Spenser, Shakespeare, John Milton, Andrew Marvell and Baudelaire. Moreover, the book of scriptures, the Buddah's Fire Sermon, Jamed Frazer's The Brilliant Bough and Jessie Weston's From Custom to Sentiment were the popular sources of Eliot's myths and images in his poetry.

Poetry reflects the poet's impression towards the universe, man and life in general. Eliot does not depend on powerful control or the bare eye to present his vision in this poem. His vision is formed by the references that translate the past and the present. Consequently, Al-Sayyab dreams are propelled by perusing myths and authentic figures of speech. Eliot's poem, The Waste Land is not a representation of nature and its remorselessness, but a presentation of the empitness of modern man. The inventive vision of the writer's lies in his capacity to draw insights from the past to interpret the present and the future:

April is the cruelest month, breeding

Lilacs out of the dead land, mixing

Memory and desire, stirring

Dull roots with spring rain.

Winter kept us warm, covering

Earth in forgetful snow, feeding

A little life with dried tubers. (Eliot, 2011, pp. 1-7)

Through his poem, The Waste Land, Eliot shows his ethical vision to the world and criticizes innovation of debasing humanistic values. Whereas, Al-Sayyab's poems show his progressive vision as well as his character and national distress. Like Eliot's The Waste Land, April is the cruelest month, A1Sayyab in his poem Madinat Al-Sindbad (The City of Sinbad) amusingly says:

Oh Spring

Oh Spring, what has afflicted you?

You have come without rain 
You have come without flowers,

You have come without fruit, And your end was like your beginning

Wrapped round in gore; now summer

Is upon us with black clouds

Its days full of cares

And its nights

We spend wakefully, counting the stars. (Khouri, 1970, p. 99)

Numerous scholars of different backgrounds compared the Middle Easterner poet, Badr Shaker Al-Sayyab with the Anglo-American poet T.S. Eliot. The Waste Land and many of Eliot's poems were translated into Arabic and published in Arabic scholarly periodicals. It is noteworthy that most of the main ideas in the poetry of T.S. Eliot has a profound impact on many innovators in the Middle East, like Al-Sayyab and Abd Al-Sabur. Through the postmodern scholarly hypotheses, comparative writings freed themselves from the subjects of root and its impact. In the same direction, this trend points to Al-Sayyab as a trailblazer instead of an imitator. Eliot's The Waste land is celebrated by Middle East writers for its condemnation of the western civilization that caused several dilemmas to humankind such as; the world wars as a kind of study of western domination. On the other hand, Eliot has continuously been criticized for his settling in England. In his poem, Little Gidding, Eliot says:

Here, the intersection of the timeless moment

Is England and nowhere. Never and always.

History is now and England. (Eliot, 2011, pp. 54-55)

Eliot's impact on Al-Sayyab was both embellished and elaborate. The formula of symbolism that Al-Sayyab utilized empowered him to forsake his emotional subjectivism and form a distinctive shift to engage his verse within the basic issues of modern poetry. A relationship was set between Eliot's use of poetic devices and his evaluation of the city within The Waste Land, and Al-Sayyab's occupation with the same subjects and comparable idyllic gadgets. Al-Sayyab's universality of his poetry was reflected in the sociopolitical unsetting and influences within the Middle Easterner region, particularly in his hometown, Jaikur. Kadhim within the same matter says:

Another sense in which - The Waste Land can be perceived as Imperialist relates to the way the poem tends to center the Western metropolis. If we allow that The Waste land, as seems plausible, is at least in part about — the immense panorama of futility and 
anarchy which is contemporary historyll, then the poem's proclamation of centrality of the West becomes all too obvious. Eliot thus assumes that - contemporary historyll is synonymous with European, he precludes the possibility of the existence of other histories which may not have been panoramas of futility and anarchy, i. e., the histories of emerging nations. (Kadhim, 1999, p. 135)

Like Eliot, Al-Sayyab stood up against the government and western authority. Through this context in 1956, Al-Sayyab states that his writings are meant to bolster the method of decolonization. He contends that the power of writing is to depict the strife between fiendish recognized colonialism and a man who battles for an opportunity. Al-Sayyab's experience with Arabic and English literary works empowered him to form his unique poetics. It is said that to borrow from other writings should be labeled as poetic plagiarism. Amid the total stage of chronicled Arabic poetry, numerous names have been given the term of borrowing from other writings such as poetic plagiarism, poetic theft, influence, acculturation hybridity or intertextuality.

In other words, the postmodern speculations coined the method of borrowing from the writings as preparation of acculturation and social hybridity, instead of plagiarism or influence. Postmodern theory's deciphering is more suitable than the Arabic hypotheses, which names the forms of borrowing and the use of references as poetic plagiarism. Additionally, there's a distinction between the term plagiarism and other terms such as; influence, acculturation, hybridity and intertextuality. Copyright infringement happens intentionally and is considered as a robbery, whereas influence, acculturation, hybridity and intertextuality occur naturally. The social hybridity between the East and the West within the Twentieth century was a result of colonialism, movement and the spread of interpretation. Al-Sayyab lives amid the colonial period and perused the world literary works through translation. Hence, numerous journalists displayed Al-Sayyab contrarily through uncovering the matching between his poetry and Eliot's poetry, which in turn decreased inventiveness and innovation.

Al-Sayyab and Eliot are socially distinctive, but with their contradictory philosophies, they share common subjects and ideas. Both poets handle the topics of desolateness, resurrection, distance, city and death. AlSayyab's idyllic procedure is compared to Eliot's method with items like; references, dialect, reiteration of words, lines and myth. Like Eliot, Al-Sayyab composed imaginative topics stamped by profound dreams of life and humanity. In addition, both poets utilize myths typically to uncover their sufferings after the world wars. Al-Sayyab and Eliot are too idealistic artists, 
as they highlighted the subject of resurrection in their poetry. Al-Sayyab legitimizes the intemperate use of myths in his poetry; and he states that the myths and images are among the noteworthy highlights of modern poetry, as myths are fundamental in composing modern poetry. Al-Sayyab uncovers that realism overwhelmed the social orders and supplanted otherworldly values.

Both Eliot and Al-Sayyab selected unprecedented titles for their poems. For instance, Al-Sayyab's poem, Unshudat Al-Matar (Rain Song) is not a melody or a poem that celebrates precipitation and uncovers the poets' bliss when he watches the raindrops. The extremity between Al-Sayyab's poem (The Rain Song) and its words uncovers the duality of his nature, the bliss and trust and the fear of losing hope. The poem shows the confusing life of Middle Easterners, who endure a parcel of hopelessness and despondency in showing disdain towards their nations. The word rain may be an image of life, richness and revival. The word song or hymn signifies bliss and cheerfulness. The poem's title shows the chattering of the feathered creatures on the trees and tunes of the children. The fowls, the children and individuals celebrate and sing when it downpours since rains imply restoration, green lands and settlement. The rain reminds Al-Sayyab of tears, death, starvation, destitution, displacement and the hopeless Iraqi people. Like Eliot, Al-Sayyab does not celebrate the season of rain, but he considers it as the cruelest season. Pain and despair within the lyrics can alter the title of the poem from rain song to rain cry.

Like Al-Sayyab, Eliot utilizes the Christian figures in his lyrics. In his poem, The Love Song of Alfred Prufrock, Eliot says: "I am Lazarus, come from the dead." (Eliot, 2011, pp.11) 'Eliot's verse is similar to Al-Sayyab's Lazarus arose from the coffin of his poem Ru'ya fi Am 1956 [Vision in 1956]. The following lines allude to the similarity between Al-Sayyab and Eliot, particularly Eliot's The Waste Land. In his poem, The Waste land, Eliot says: "From which a golden Cupidon peeped out" (Eliot, 2011, p.80). Similarly, A1Sayyab's line in his poem, Al-Mumis Al-Amyal (The Blind Harlot) refers to the golden arrows of Cupid: As long as the golden arrows whistle in the air. In The Waste Land, Game of Chess, Eliot' line, "The wind under the door." is relatively similar to Al-Sayyab's line, "The door was not knocked on, but the wind." (Al-Sayyab, 2000, p.47) In The Waste Land, Eliot employs the theme of rebirth without mentioning the names of the Gods as Al-Sayyab does. Eliot says:

That corpse you planted last year in your garden,

Has it begun to sprout? Will it bloom this year?

Or has the sudden frost disturbed its bed?

O keep the Dog far hence, that's friend to men,

Or with his nails he'll dig it up again! (Eliot, 2011,

pp.71-75) 
Essentially, Al-Sayyab in his poem, Cerberus in Babel, alludes to the theme of revival. He uses the ancient myths especially through mentioning the canine of hell, Cerberus and the God of growth and fertility, Tammuz; however, Eliot certainly alludes to the theme resurrection. Eliot uses the image of the typical dog that may exhume human beings. On the other hand, AlSayyab utilizes the legendary dog that burrows up the legendary dead Tammuz:

Let Cerberus growl in the routes

And exhume our buried god

That is our stabbed Tammuz. (Al-Sayyab, 2000, pp. 49)

The component of intertextuality between Al-Sayyab's poems and Eliot's The Waste Land is highly-observed. Through the flowing lines, Eliot and Al-Sayyab referred to the Phoenician sailor who suffocates within the ocean. Both Eliot and Al-Sayyab declare in their notes that they referred to Shakespeare's play, The Tempest. In The Waste Land, Eliot says:

Is tour card, the drowned Phoenician Sailor, (Those are pearls that were his eyes. Look!) Phlebas the Phoenician, a fortnight dead.

Forget the cry of gulls, and the deep sea swell And the profit and loss.

A current under sea

Picked his bones in whispers. (Eliot, 2011, pp. 47-48, 312-316)

Perceivably, these lines are just similar to Al-Sayyab's poem Min Ru'ya Fukai (From Fukai 's Vision) in which Al-Sayyab says:

Your father, the explorer of the ocean, slept in

the depths Pearls from his eyeballs that

merchants sell. (Al-Sayyab, 2000, pp. 50-51)

Essentially, in his poem Unshudat al-Matar [Rain Song], AlSayyab also implies to the myth of the suffocate Phoenician mariner when he says:

The Gulf casts its abundant gifts on the sand:

Foam, shells and the bones of an emigrant

Who drank death At the bottom of the Gulf

(Al-Sayyab, 2000, p.52)

In the fifth section of The Waste Land, What the Thunder Said, Eliot employs the motif of rain as a symbol of life and fertility: 
The shouting and the crying

Prison and place and reverberation

Of thunder of spring over distant mountains

Where the hermit-thrush sings in the pine trees

Drip drop drip drop drop drop drop

But there is no water. (Eliot, 2011, pp. 325-

327, 356-358)

Comparing Eliot's above-lines with Al-Sayyab's following lines, the intertextuality between them is observed:

As if the rainbow drinks the clouds

And drop by drop melts in rain

And children babble under vine trellises

And the song of rain

Tickles the silence of birds on the trees

Rain ...

Rain ...

Rain... (Al-Sayyab, 2000, pp. 6-13)

Al-Sayyab and Eliot used the theme of water contrarily. Within the opening lines of The Waste Land, Eliot delineates the season of rain as the cruelest month: April is the cruelest month, breeding / Lilacs out of the dead land, mixing / Memory and desire, stirring / Dull roots with spring rain. (Eliot, 2011, pp.1-7) Eliot entitles the fourth section of The Waste Land, Death by Water. Essentially, Al-Sayyab shows a negative image of water when he says:

I cry to the Gulf, -O Gulf,

$\mathrm{O}$ giver of shells and death

The echo comes back

Like sobs,

-O Gulf,

$\mathrm{O}$ giver of shells and death.

I can almost hear Iraq gathering thunder

And storing up lightning in mountains and

plains. (Al-Sayyab, 2000, pp. 1-8)

Similarity between Al-Sayyab's poem Madina Bila Matar [City without Rain] and Eliot's, The Waste Land is obvious in the following lines:

But years have passed, so many we have not counted

them

With no rain- not even a drop,

With no flowers- not even flower. 
With no fruits: as if our barren palms were idols we erected.

So that we might wither and die under them. (Eliot, 2011, pp. 5-9)

In his poem Ru'ya fi Am 1956 [Vision in 1956] Al-Sayyab quotes Eliot's title of his poem The Waste Land when he says:

Which crowd of gloomy faces,

Of hands like the dust,

Its plant is shingles and steel like the waste

land? (Al-Sayyab, 2000, pp. 3-5)

Intertextuality is additionally observed between Al-Sayyab and the Spanish poet, Federico García Lorca and the English poetess Edith Sitwell. Al-Sayyab borrows a few of his wonderful images from Lorca, and Sitwell. For instance, in his poem Al-Nahr wa Al-Mawt [The River and Death], Al-Sayyab says:

Bells of a tower lost in the sea bed

Dusk in the trees, water in the jars

spilling rain bells

crystals melting with a sigh

My death bells ring and shake my veins.

(Khouri Trans, 1970, p. 57 )

The idyllic image of the above lines is generally similar to Lorca's poetic pictures of his poem, Ballad of the Small Plaza, in which Lorca says:

A peal from the bell-tower, lost in the dimness.

It's filled with light, is

my heart of silk, and

with bells that are lost,

with bees and with lilies (Lorca, 2019, p. 58)

Al-Sayyab also borrows from Lorca images of the moon when he says:

I want to peer across the crests of the hills, catch sight of the moon

as it wades between your banks, planting shadows filling baskets with water and fish and flowers .

I want to plunge into you, following the moon, 
hear the pebbles hiss in your depths.

(Al-Sayyab, 2000, p. 59)

Similarly, in his poem - Romance Sonámbulo, Lorca says:

High verandas of the moonlight,

where I hear the sound of waters.

Now they climb, the two companions,

up there to the high veranda,

letting fall a trail of blood drops,

letting fall a trail of tears. (Lorca, 2019, p. 12)

In his sonnet - Tammuz Jaikur [Tammuz of Jaikur], Al-Sayyab says: "Boar's tusk rends my hand". This line is similar to Lorca's lines in The Death of Tony Camborio, "He slashed their leather boots / with the tusks of a wild boar". For instance, Al-Sayyab in his poem, Ru'ya Fukai [From Fukai's Vision] says:

Did Gypsy in Granada intend to depart?

Then, the winds, the brook and the moon

became green? (Al-Sayyab, 2000, pp. 61-62)

\section{Conclusion}

Like Eliot, Al-Sayyab uses verifiable and various myths; he incorporates the myth of Tammuz and Ishtar to represent the cycle of death and birth. He, moreover, employs the Babylonian myth and the Sphinx myth to criticize oppression and persecution. His poetry expresses a profound association between the man on one hand and life on the other hand. AlSayyab's verse demonstrates the themes of revival and reestablishment as basic human needs. Therefore, his poetry uncovers how life and death are interwoven; and how trust and pity are interrelated. It is no wonder that blood and tears are linked in his poetry. Al-Sayyab employs myths such as legendary images and paradigms. He gets to be the spokesperson of the national concern by speaking to Middle easterners' administrations in a legendary outline; hence, carrying his poetry to an all-inclusive level whereas changing prevalent myths as an Iraqi Arab poet. Even though this paper has revealed a few beneficial impact relations inside an innovator setting, his poems stay luxuriously critical and commendable of examination on his possess. Also, different contexts have been utilized as an interpretive key to the poems, i.e. the western poetry in Eliot, Sitwell and Loreca.

This paper tries to compare the effect of modernism on Arabic and English poetry, and it highlights the merging between them as epitomized by their pioneers. There are two points of view of defining the term modernism: one is that modernism may be an infringement of standard and endeavors to 
break the convention. It reflects the traditional values and energizes inventiveness and subjectivity. The other point of view sees modernism as a response to the brutal urban societies, industrialization and the disappearance of human values. From the western viewpoint, modernism may be advancement within the western society which places man as the center of the universe, that judges all things on earth rather than following the standards of his ancestors. It includes all development in craftsmanship, engineering and writing; which endeavored to break with classical and conventional norms. Generally, modernism could be a period, fashion and class. From an Arab viewpoint, modernism is an awareness of life and existence. It could be a revolt against injustice; it could be an infringement of political, moral and social change. It rejects the ideal measures of the past. Modernism is connected to innovation and it is a continued movement through time and places. Arab modernism could be an unusual and insightful vision of the self and the universe.

\section{References:}

1. Al-Sayyab, B.S. (2000)Full Poetic Collection (3rd ed.), Ed. and Intro. Naji Allosh, Baghdad: Dar al- Hurria Publications.

2. ..............(4-4-2019)

https://www.academia.edu/7126337/Engaging_T.S. Eliot City

Narratives in The Poetry Badr Shaker Al-Sayyab.

3. Abbas, Abd al-Jabbar. (1966) "Al-I;Iubb wa al-Mala ff Shi alSayyab," Al-AdQb Vol.2, pp.5-7,78-79.

4. Badawi, M.M. (1975). A Critical Introduction to Modern Arabic Poetry. Cambridge: Cambridge University Press.

5. Eliot, Thomas Stearns. (2011). The Waste Land. New York: Horace Liveright, 1922; Bartleby.com,

6. http://www.columbia.edu/itc/history/winter/w3206/edit/tseliotlittlegi dding.html. Little Gidding. ......3-2-2019

7. .......2-1-2019. https://allpoetry.com/The-Hollow-Men.

8. Emran, S. (2000) Imagery and Its Symbolic, Mythical and Expressionistic Patterns in ThePoetry of T.S. Eliot And Badr Shaker Assayyab, M.A. Thesis,Supervised by M.T. Al- Bujairami and Atif Faddul, Univ. of Damascus.

9. Gohar, S.M. (2008) The City/Country Dialects in the Poetry of Eliot and Al-Sayyab, InterCulture, 184-204.

10. Haidar, Haj Ali. (1986). London. Third World Center for Research and Publishing. (7-8

11. Issa J, Boullata. (1976). trans and ed, Modern Arab Poets 1950-1975. (London: Heinemann) 
12. Kadhim, H.N. (1999), Rewriting The Waste Land: Badr Shakir AlSayyab's 'Fi Al-Maghrib Al-Arabi. Journal of Arabic Literature, 128165.

13. Khouri, Mounah. (1970), "Lewis A wad, A Forgotten Pioneer of The Free Verse Movement." Journal of Arabic Literature. (1) p. 137.

14. .............. (1975).Trans, An Anthology of Modern Arabic Poetry. (California: University of California Press)

15. Lorca, Garcia. (3- 4-2019).

<http://www.poetryintranslation.com/PITBR/Spanish/Lorca.htm>. 